\title{
Living shorelines can enhance the nursery role of threatened estuarine habitats
}

\author{
Rachel K. Gittman,,${ }^{1,4}$ Charles H. Peterson, ${ }^{1}$ Carolyn A. Currin, ${ }^{2}$ F. Joel Fodrie, ${ }^{1}$ Michael F. Piehler,${ }^{1}$ \\ AND JOHN F. BRUNO ${ }^{3}$ \\ ${ }^{1}$ Institute of Marine Sciences, University of North Carolina at Chapel Hill, Morehead City, North Carolina 28557 USA \\ ${ }^{2}$ Center for Coastal Fisheries and Habitat Research, National Oceanographic and Atmospheric Administration, Beaufort, North \\ Carolina 28516 USA \\ ${ }^{3}$ Department of Biology, University of North Carolina at Chapel Hill, North Carolina 27599 USA
}

\begin{abstract}
Coastal ecosystems provide numerous services, such as nutrient cycling, climate change amelioration, and habitat provision for commercially valuable organisms. Ecosystem functions and processes are modified by human activities locally and globally, with degradation of coastal ecosystems by development and climate change occurring at unprecedented rates. The demand for coastal defense strategies against storms and sea-level rise has increased with human population growth and development along coastlines worldwide, even while that population growth has reduced natural buffering of shorelines. Shoreline hardening, a common coastal defense strategy that includes the use of seawalls and bulkheads (vertical walls constructed of concrete, wood, vinyl, or steel), is resulting in a "coastal squeeze" on estuarine habitats. In contrast to hardening, living shorelines, which range from vegetation plantings to a combination of hard structures and plantings, can be deployed to restore or enhance multiple ecosystem services normally delivered by naturally vegetated shores. Although hundreds of living shoreline projects have been implemented in the United States alone, few studies have evaluated their effectiveness in sustaining or enhancing ecosystem services relative to naturally vegetated shorelines and hardened shorelines. We quantified the effectiveness of (1) sills with landward marsh (a type of living shoreline that combines marsh plantings with an offshore low-profile breakwater), (2) natural salt marsh shorelines (control marshes), and (3) unvegetated bulkheaded shores in providing habitat for fish and crustaceans (nekton). Sills supported higher abundances and species diversity of fishes than unvegetated habitat adjacent to bulkheads, and even control marshes. Sills also supported higher cover of filter-feeding bivalves (a food resource and refuge habitat for nekton) than bulkheads or control marshes. These ecosystem-service enhancements were detected on shores with sills three or more years after construction, but not before. Sills provide added structure and may provide better refuges from predation and greater opportunity to use available food resources for nekton than unvegetated bulkheaded shores or control marshes. Our study shows that unlike shoreline hardening, living shorelines can enhance some ecosystem services provided by marshes, such as provision of nursery habitat.
\end{abstract}

Key words: bulkhead; coast; ecosystem service; erosion; fish; nekton; salt marsh; seagrass; sea-level rise; shoreline stabilization; sill; subtidal breakwater

\section{INTRODUCTION}

Ecosystem services are the direct and indirect benefits that humans derive from ecosystems, and in coastal environments include nutrient cycling, climate

Manuscript received 15 April 2014; revised 3 April 2015; accepted 21 April 2015. Corresponding Editor: S. P. Faulkner.

${ }^{4}$ Present address: Marine Science Center, Northeastern University, Nahant, Massachusetts 01908 USA. E-mail: r.gittman@neu.edu regulation, habitat provision for organisms of value, and recreational uses (Carpenter et al. 2009). Many human activities are degrading coastal ecosystems and the services they provide (Vitousek et al. 1997, Millennium Ecosystem Assessment [MEA] 2005, Dahl and Stedman 2013). Coastal development and global climate change, particularly sea-level rise and increased storm frequency and intensity, are threatening coastal ecosystems and have already resulted in significant losses of these ecosystems (MEA 2005, Hoegh-Guldberg 
and Bruno 2010). With nearly $40 \%$ of the world's population living within $100 \mathrm{~km}$ of a coastline (MEA 2005), there is considerable need for development strategies that sustain, restore, or enhance delivery of these globally important ecosystem services (Carpenter et al. 2009).

One of the most pressing concerns over continued coastal development is protection against erosion and subsequent property loss resulting from the joint impacts of storm events and sea-level rise (Törnqvist and Meffert 2008, Temmerman et al. 2013). Traditional shoreline protection methods, such as seawalls or bulkheads, are designed to protect the shore from erosion and public or private infrastructure from flood and structural damage, but can fail during major storm events and even exacerbate impacts (Thieler and Young 1991, Gittman et al. 2014). In contrast to the putative erosion and damage protection for upland property, these structures can also induce erosion of habitats located seaward of or adjacent to the structure, resulting in the loss of valuable intertidal and/or shallow vegetated (e.g., salt/brackish/fresh marsh, seagrass, mangrove), beach, or mudflat habitat (Hall and Pilkey 1991, Doody 2004, Bozek and Burdick 2005, Dugan et al. 2008, Pontee 2013). Further, as sea levels rises, a "coastal squeeze" can occur where coastal habitat is lost from the high intertidal zone being held at a constant position by a structure and the low intertidal zone migrating landward (Titus 1998, Pontee 2013). Additionally, bulkhead and seawall shorelines support a lower abundance and diversity of benthic infauna, fish, and mobile crustaceans than natural shorelines dominated by salt marsh (Seitz et al. 2006, Bilkovic and Roggero 2008, Dugan et al. 2008, Lucrezi et al. 2010). Heightened awareness of the adverse ecological effects of "hard" shoreline protection methods and the billions of dollars in damage done to coastal properties and infrastructure by major storm events (e.g., Hurricane Katrina in 2005 and Superstorm Sandy in 2012 in the United States) have increased demand for alternative methods that incorporate natural components for coastal protection (Arkema et al. 2013, Cheong et al. 2013, Gittman et al. 2015).

Some alternative methods of coastal protection, broadly termed "living shorelines," include restoration of habitats that provide natural protection from erosion, such as salt marshes and intertidal oyster reefs (Crooks and Turner 1999, Piazza et al. 2005). Living shorelines also include hybrid techniques that consist of pairing an offshore sill composed of granite boulders, concrete, marl, or oyster shell with marsh plantings (referred to as sill hereafter, see Fig. 1 for examples of sills; National Research Council [NRC] 2007, Currin et al. 2009). Over 200 projects identified as living shorelines have been permitted and constructed in the United States, with sills comprising more than half of them (Fear and Bendell 2011, Chesapeake Bay Trust 2014, Coasts, Oceans, Ports and Rivers Institute [COPRI] 2014). The goals of these projects are to go beyond providing erosion protection to include sustaining additional ecosystem services, such as provision of habitat for various marine organisms and filtration of nutrients or pollutants (Coasts, Oceans, Ports, and Rivers Institute (COPRI) 2014). However, few studies have assessed the success of living shoreline approaches in sustaining or enhancing ecosystem services (but see Currin et al. 2007, Scyphers et al. 2011, La Peyre et al. 2014). Furthermore, existing studies have only evaluated the short-term ecological functions of living shorelines $(<3$ years postconstruction) and have not included comparisons to the ecological functions of bulkheaded shores.

We hypothesized that hybrid living shorelines, sills with landward marsh, would support higher abundances, biomass, and diversity of mobile fishes and crustaceans (nekton), particularly juveniles and estuarine residents, than fringing salt marshes alone or than unvegetated bulkheads. Our hypothesis is based on the expectation that sills would enhance preexisting uses of habitat through one or both of the following mechanisms: (1) increasing the structural complexity of the habitat and providing spatial refuge from predation and environmental stress (i.e., wave exposure); and (2) increasing resource (food) availability via providing additional substrata for epibiota (prey) and organic matter deposition. Nekton abundance and production are positively related to structural habitat complexity, such as submerged aquatic vegetation (Orth et al. 1984, Bell and Westoby 1986), oyster reefs (Grabowski and Peterson 2007, Grabowski et al. 2008, Stunz et al. 2010), and salt marshes (Peterson and Turner 1994, Minello et al. 2003) relative to mudflat or sandy bottom habitats, which lack emergent structure. The addition of sills may increase the availability of structured habitat by providing novel substrate for the settlement of foundation species such as oysters and mussels, and may increase the deposition of other organic materials as food resources (Peterson et al. 2003). To test our hypothesis, we compared nekton catch rates and diversity along sills of varying ages (0-8 years) to shorelines with natural, fringing salt marshes, and to bulkheaded shorelines without marsh.

\section{Methods}

\section{Study design}

To ensure our study would provide a comprehensive assessment of nekton use of habitats associated with different shore stabilization approaches, we made four independent comparisons of nekton catch rates along different types of shorelines. We first compared nekton catch rates and diversity in intertidal marsh (Appendix S1: Fig. S1A) and shallow subtidal habitat (Appendix S1: Fig. S1B) between sites with sills (three or more years after sill construction) and sites without sills (control marsh sites), referred to as the control-impact 


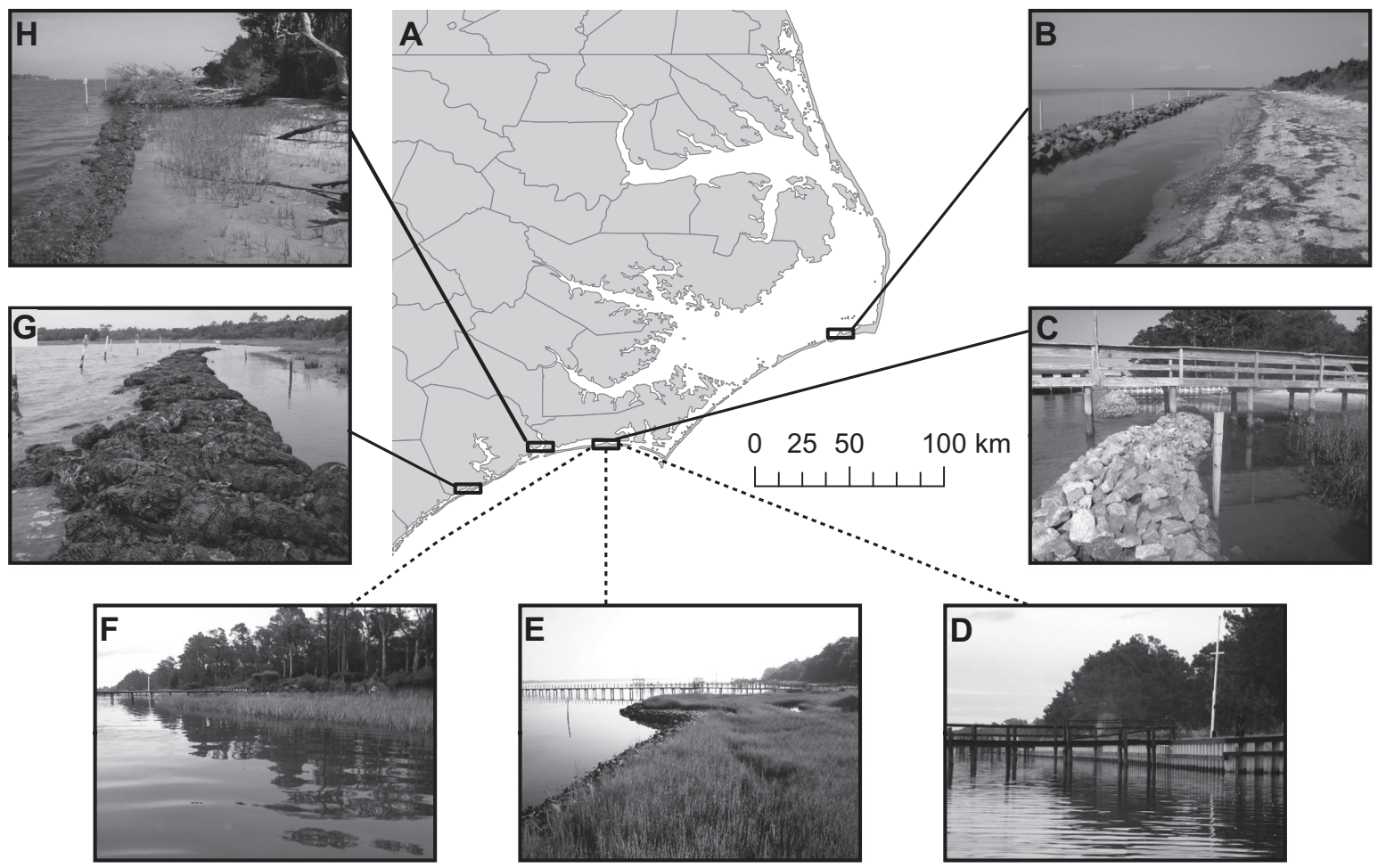

FIG. 1. (A) Map of locations of the (B) before-after-control-impact (BACI) sill site and control marsh site (not pictured) on Hatteras Island, Outer Banks, North Carolina, USA; (C) BACI sill, (D) bulkhead (one of three), (E) control-impact (CI) sill (one of three), and (F) control marsh sites (one of three) in Pine Knoll Shores (PKS), North Carolina; (G) the BACI oyster bag sill site and control marsh site (not pictured) at Morris Landing, Holly Ridge, North Carolina; and (H) the BACI oyster bag sill site and control marsh site (not pictured) on Jones Island, Swansboro, North Carolina. Solid lines to photographs indicate BACI sites and dotted lines to photographs indicate CI sites. As shown in the photographs, the BACI and CI sills have varied designs in terms of structure material (granite vs. oyster shell) and different distances between breaks in the sill. Photo credit: R. K. Gittman.

(CI) study. We also compared nekton catch rates and diversity in intertidal marsh and shallow subtidal habitat before and after sill construction to nekton catch rates and diversity at control sites, referred to as the before-after-control-impact (BACI) study. We then determined if nekton catch rates and diversity in habitat adjacent to sills differed between a newly constructed sill and sills that had been in place for three or more years (the period of time estimated to be necessary for nekton to respond to new habitat; La Peyre et al. 2014). To make this determination, we compared nekton catch rates and diversity at a BACI sill less than 1 yr after construction and at three CI sill sites (one sill $3 \mathrm{yr}$ and two sills $8 \mathrm{yr}$ after construction) within the same geographic region. Finally, we compared nekton catch rates and diversity in unvegetated intertidal habitat adjacent to sills, adjacent to bulkheads with no marsh, and adjacent to control marsh sites (Appendix S1: Fig. S1S3), referred to as the bulkhead comparison (BC) study. To identify factors (e.g., increased structural complexity) potentially associated with differences in nekton catch rates and diversity among different shoreline types, we also measured habitat characteristics at each shoreline type.

\section{Description of study sites}

The CI study consisted of surveying three existing granite sills and three control marsh sites located in Pine Knoll Shores (PKS), North Carolina, USA (Fig. 1A; 34 $42^{\prime} 11^{\prime \prime} \mathrm{N}, 76^{\circ} 48^{\prime} 21^{\prime \prime} \mathrm{W}$ ). At each sill site, a sill consisting of piled granite boulders $(20-50 \mathrm{~cm}$ diameter) was constructed between 2002 and 2007 (Fig. 1E). The elevation of the base of each sill was between 0.14 and $0.31 \mathrm{~m}$ below mean sea level (MSL). Each sill had a mean height ranging from $0.2 \mathrm{~m}$ (base to top of the sill) for the oldest sill to $0.56 \mathrm{~m}$ for the youngest sill. Each sill also had either a drop-down (area of lower elevation interrupting the sill crest; Appendix S1: Fig. S2S1) or an overlapping gap (a break in two sill sections; Appendix S1: Fig. S2S2) to allow water to flow behind the sill at intervals of every $\sim 20 \mathrm{~m}$ for the entire length of the sill (range: 40-100 m long). Marsh grasses, Spartina alterniflora and $S$. patens, were planted behind each sill along the lower 
edge of existing marsh at elevations consistent with the positions of these two grasses in nearby unmodified marshes (Currin et al. 2007; J. Shallcross and J. Best, personal communication). To minimize site-specific differences that may affect nekton catch rates, we paired each sill site with a control site with similar physical characteristics (e.g., marsh width, wave exposure) and close proximity $(<200 \mathrm{~m})$ along the same shoreline (Fig. 1F).

BACI sites were located in PKS, Hatteras $\left(35^{\circ} 13^{\prime} 18^{\prime \prime}\right.$ N, $\left.75^{\circ} 41^{\prime} 35^{\prime \prime} \mathrm{W}\right)$, Swansboro (34⒋ $41^{\prime} 49^{\prime \prime} \mathrm{N}, 77^{\circ} 6^{\prime} 24^{\prime \prime}$ $\mathrm{W})$, and Holly Ridge, North Carolina $\left(34^{\circ} 28^{\prime} 12^{\prime \prime} \mathrm{N}\right.$, $77^{\circ} 30^{\prime} 28^{\prime \prime}$ W; Fig. 1A). At each site, a low sill, consisting of granite boulders (Hatteras and PKS, Fig. 1B,C) or oyster shell bags (Holly Ridge and Swansboro, Fig. $1 \mathrm{G}, \mathrm{H})$, was constructed to a height just above MSL. Each sill had a mean height ranging from 0.3 $\mathrm{m}$ (oysterbag sills) to $0.7 \mathrm{~m}$ (stone sills). As with our CI sites, S. alterniflora (low marsh) and S. patens (high marsh) were planted behind the sill at elevations consistent with nearby marshes. The Swansboro, Hatteras, Holly Ridge, and PKS sills were constructed in September 2010, March 2011, November 2011, and April 2012, respectively. The Swansboro and Hatteras sill sites were planted in May 2011 and the Holly Ridge sill site was planted in May 2012. The PKS sill site was not planted during the study period. A marsh control site was selected as described for CI sites. The PKS sill site from this BACI study was also compared to the CI study sill sites to test for the effects of sill age on ecosystem service delivery (nekton use).

For the BC study, we selected three bulkheaded sites with no seaward marsh in PKS along the same shoreline as the CI sills and control marshes (Fig. 1DF). Each bulkhead consisted of a vertical vinyl wall constructed at the observed high water mark (OHWM) or $\sim 0.59 \mathrm{~m}$ above MSL (tide data available online). ${ }^{5}$

\section{Nekton sampling}

We conducted all nekton sampling monthly from June to October, with CI, BACI, and BC sampling occurring in 2010, from 2010 to 2012, and in 2011, respectively. We sampled nekton utilizing the marsh (defined here to include the marsh interior, marsh edge, and unvegetated mudflat within $3 \mathrm{~m}$ of the marsh edge) at paired sill and control marsh sites (CI study) by simultaneously setting two fyke nets at each site during a night spring high tide and recovering gear during the subsequent low tide ( 6-h sets; Appendix S1: Fig. $\mathrm{S} 1 \mathrm{~S} 1)$. Fyke nets were placed at the sill drop-downs or gaps at the sill sites (Appendix S1: Fig. S13) and haphazardly along the edge of control marsh sites. Fyke net openings were set at approximately the same distance from the marsh edge (3-5 m, depending on sill location relative to the marsh edge) at each paired site (Rozas

\footnotetext{
${ }^{5}$ http://tidesandcurrents.noaa.gov/waterlevels.html?id=8656483
}

and Minello 1997, Currin et al. 2007). The fyke nets consisted of a $0.9 \times 0.9 \times 5.1 \mathrm{~m}$ compartmentalized, 3.175-mm-mesh bag with $0.9 \times 5.1 \mathrm{~m}$ wings that stretched out from the bag (set for a total mouth width of 8 $\mathrm{m})$. To determine nekton catch rates and diversity of subtidal habitats adjacent to sills and at control sites (CI study), we seined two times parallel to the shoreline for $20 \mathrm{~m}$ ( $\sim 5 \mathrm{~m}$ from the sill or marsh edge) at each site during afternoon spring low tides (Appendix S1: Fig. S1S2). Seines were $7.3 \mathrm{~m}$ wide by $1.8 \mathrm{~m}$ tall, made from 3.175-mm mesh, and included a $1.8 \times 1.8 \times 1.2$ $\mathrm{m}$ bag. Nekton use of unvegetated subtidal habitat within $1 \mathrm{~m}$ of sills (between the sills and landward marsh edges), and seaward of bulkheads and control marshes was assessed by setting replicate $(n=10)$ minnow traps (3.175-mm-galvanized mesh) at the edge of each shoreline type $2 \mathrm{~h}$ before high tide and collecting the traps $2 \mathrm{~h}$ after high tide (Appendix S1: Fig. S1S3). We opted for a maximum minnow trap soak time possible for our study sites, as the unvegetated edge of the marsh and mudflat adjacent to the bulkheads samples becomes exposed $3 \mathrm{~h}$ after high tide. Our results are nonetheless conservative measures of abundance, and observed differences between sills, control marshes, and bulkheads are likely greater than what was observed in our study. This interpretation of soak time bias is consistent with Teo and Able (2003), who also found large differences between sites with a soak time of greater than $60 \mathrm{~min}$ and assumed that these differences were conservative.

Nekton was identified to species, when possible, counted, and weighed wet, before the first 20 of each species were measured for standard length (fish and shrimp) or carapace length (crabs) either in the field or in the lab (after being held or transported using buckets and air bubblers), with subsequent release. All species were classified as resident or transient and the mean length and biomass data were used to determine if a majority of individuals were juveniles or adults for each species, as per Hettler (1989) and Peterson and Turner (1994). We pooled across nets or traps at each site and abundance data are reported as catch per unit effort (CPUE) for nekton caught by all nets or traps per site per sampling effort (individuals or grams per set). Sampling effort was standardized as two fyke nets soaking for $6 \mathrm{~h}$, two $20-\mathrm{m}$ seine pulls, and 10 traps soaking for $4 \mathrm{~h}$.

\section{Habitat characteristics}

We measured several habitat characteristics (e.g., marsh surface elevation, marsh macrophyte density, sediment organic matter [SOM] content) to better assess the relationship between shoreline type and nekton use of available habitats. To characterize the intertidal habitat structure available to nekton, we quantified total stem density of marsh macrophytes at each CI and BACI site. Five intertidal transect locations were 
selected using restricted random (between 10 and 20 $\mathrm{m}$ apart to maintain independence) sampling (Neckles et al. 2002). Transects began at the seaward edge of the marsh and continued to the start of shrub-scrub vegetation or to property-owner landscaping. Marsh plots were established at 3- or 5-m intervals along each transect beginning at the lower marsh edge. The length of each transect $(5-20 \mathrm{~m})$ and total number of marsh plots established (9-21) depended on the marsh width from seaward edge to upland vegetation at each site. Stem density was measured by marsh plant species per $0.25-\mathrm{m}^{2}$ plot (Daoust and Childers 1998). Total stem density of marsh plants was calculated by summing the stem densities of all species present within a plot. We surveyed subtidal areas up to $20 \mathrm{~m}$ seaward of the marsh edge to determine the type of subtidal habitat available to nekton at all $\mathrm{CI}$ and BACI sites (e.g., sand/mud flat, seagrass, or both). Sampling plots began at the lower marsh edge and seagrass shoot density was estimated every $5 \mathrm{~m}$ along each transect by counting the total number of shoots per species inside $0.25-\mathrm{m}^{2}$ quadrats (Hauxwell et al. 2001).

Surface elevation was measured within $1 \mathrm{~m}$ landward of the sill using a leveling rod and rotary laser level and referencing the measurements to semipermanent benchmarks (points established on a stable structure with unchanging elevation, e.g., a piling or tree) with elevations determined using a Trimble Virtual Reference Station (VRS; Trimble, Sunnyvale, California, USA), Real Time Kinematic (RTK), Global Positioning System (GPS). North American Vertical Datum of 1988 (NAVD88) elevations obtained using these methods are estimated to be accurate to $\pm 6 \mathrm{~cm}$ (P. Hensel, personal communication). To determine the availability of organic material available to benthic or filter-feeding nekton, we took sediment organic matter (SOM) samples by coring the top $3-5 \mathrm{~cm}$ of sediment at every plot on all site transects. Cores were transported to the lab and frozen for later analysis. For SOM analysis, a homogenized subsample of $\sim 30 \mathrm{~g}$ (wet mass) was dried overnight at $100^{\circ} \mathrm{C}$, weighed, and then ashed at $450^{\circ} \mathrm{C}$ for $6-8 \mathrm{~h}$ and reweighed to obtain ash-free dry mass by subtraction (Currin et al. 2007). To determine availability of epibiota (macroalgae and invertebrates) at sill, control marsh, and bulkhead sites, we sampled the sills (granite), control marsh edges (unconsolidated sediment), and bulkheads (vinyl) in September 2011. We determined the proportion and composition of epibiotic organisms attached to the substrate by determining the presence/absence of each species at each of 16 intercepts in situ using the point-intercept method within a $0.25-\mathrm{m}^{2}$ quadrat with a monofilament grid (Drummond and Connell 2005).

\section{Statistical analyses}

Because of natural environmental variability among our sites (e.g., proximity to channels, shoreline orientation, sample date), we paired our CI sill and control marsh sites for all analyses. We compared catch rates and Shannon-Wiener diversity indices $\left(H^{\prime}\right)$ of nekton between paired CI sill sites and control marsh sites using grouped (by site), matched-pairs two-tailed $t$ tests. Catch rates of nekton were analyzed separately for each habitat (marsh samples using fyke nets or subtidal samples using seines). We applied a sequential Bonferroni correction (Holm 1979), correcting from an initial alpha level of 0.05 , separately to the following families of matched-pair $t$ tests: (1) individuals, biomass ( $\mathrm{g}$ ), and diversity of fishes per fyke net set sampled in marsh habitat; (2) individuals and biomass (g) of crustaceans per fyke net set sampled in marsh habitat; (3) individuals, biomass (g), and diversity of fishes per seine net set sampled in seagrass habitat; and (4) individuals and biomass ( $\mathrm{g}$ ) of crustaceans per seine net set sampled in seagrass habitat. We grouped our analyses into families based on the habitat sampled (marsh or subtidal habitat) and the organism group sampled (e.g., fishes or crustaceans; Appendix S2: Table S2).

We also compared the mean total stem density (per $\mathrm{m}^{2}$ ) of marsh plants, sediment surface elevation 1-m landward of the sill, and SOM (\%) within the marsh using matched pairs two-tailed $t$ tests. To determine if seagrass habitat varied between sill and control sites as a function of distance from the marsh edge $(1,5$, 10,15 , and $20 \mathrm{~m}$ ), we compared mean total shoot density (per $\mathrm{m}^{2}$ ) of all seagrasses at sill and control sites using a generalized linear model (GLM). An alpha level of 0.05 was used for the individual site characteristic tests.

To compare the catch rates of nekton between BACI sill sites and control marsh sites before and after the sills were constructed, we performed separate BACI analyses (two-way ANOVAs) for each site, with treatment (sill vs. control marsh), time (before vs. after), and treatment $\times$ time as fixed factors. Sequential Bonferroni corrections were applied as described for CI analyses of nekton catch rates (Appendix S2: Table S1).

We compared the mean differences in nekton catch rates between the three CI sills and control marsh sites in PKS to the mean difference between the BACI sill $(<1$ yr post-construction) and control marsh in PKS site using a one-sample $t$ test (transforming all sill-minus-control data so that BACI differences would equal 0$)$. We also compared the mean surface elevation 1-m landward of the sill, SOM, and stem density of marsh macrophytes between each CI sill and the BACI sill using a one-sample $t$ test. An alpha level of 0.05 was used for the individual site characteristic tests.

We compared nekton catch rates between sill, control marsh, and bulkhead-with-no-marsh sites using nested analyses of variance (ANOVAs) with treatment (sill vs. control vs. bulkhead) as a fixed factor and sampling month nested within each site. 
We preferred a nested ANOVA over the matched paired analysis used to compare the sills and control marsh sites alone because unvegetated bulkhead sites could not be appropriately paired geographically to the sill and control marsh sites. Sequential Bonferroni corrections were applied as described for $\mathrm{CI}$ and BACI analyses of nekton catch rates (Appendix S2: Table S21).

Catch rates, density of marsh plants, and shoot density of seagrass were log-transformed prior to analysis to meet the assumptions of normality (Shapiro-Wilk Test, $P>0.05$ ) and homogeneity of variance (Levene's test, $P>0.05$ ). Analyses were conducted using JMP 10.0 (SAS Institute, Cary, North Carolina, USA).

Epibiotic cover data were pooled into three functional groups (bivalves, barnacles, and other foulers) and analyzed separately based upon the hypotheses that bivalve cover (oysters and mussels) should be higher on sills and along marshes than on bulkheads and that barnacle and other fouling organism cover would be lower at sites with a higher cover of bivalves. All fouling organisms other than barnacles (primarily sponges, bryozoans, and tunicates) were pooled together because their total proportion of cover was less than 0.1 across all treatments. The proportion of cover for each pooled group was zero-inflated and did not meet the assumptions of normality; therefore, we performed separate, nonparametric permutational multivariate analyses of variance (PERMANOVAs) on the Euclidean distance matrices of the univariate proportion of cover of bivalves, proportion of barnacles, and pooled proportion of other epibiota to decipher significant differences between sills, bulkheads, and control marshes. Performing a PERMANOVA on the Euclidean distance of a univariate response variable, such as total proportion of cover of barnacles, is equivalent to performing a univariate ANOVA, with the exception that the $P$ values for a PERMANOVA are calculated using permutations rather than tabled $P$ values, and thus do not assume normality of the data (Anderson 2005). Permutational dispersion (PERMDISP) was used to test for homogeneity of variances. PERMANOVA analyses were conducted using PRIMER-E software 6.1.1 with PERMANOVA+ 1.0.1 (Clarke and Gorley 2001, Anderson 2005).

\section{Results}

\section{CI comparison}

We found higher catch rates of fishes within the marsh at sill sites than at control sites (Fig. 2A, individuals per two fyke net sets, $t$ ratio $=-4.61, \mathrm{df}=$ $14, P>|t|=0.0004$, and Fig. 2B, biomass per two fyke net sets, $t$ ratio $=-3.44, \mathrm{df}=14, P>|t|=$ $0.004)$. For crustaceans, we also caught more individuals per two fyke net sets within the marsh at sill sites than at control sites (Fig. 2A, $t$ ratio $=-4.13$, df $=$ $14, P>|t|=0.001)$, but differences in crustacean biomass per two fyke net sets were nonsignificant between sill and control sites (Fig. 2B, $t$ ratio $=-1.83$,
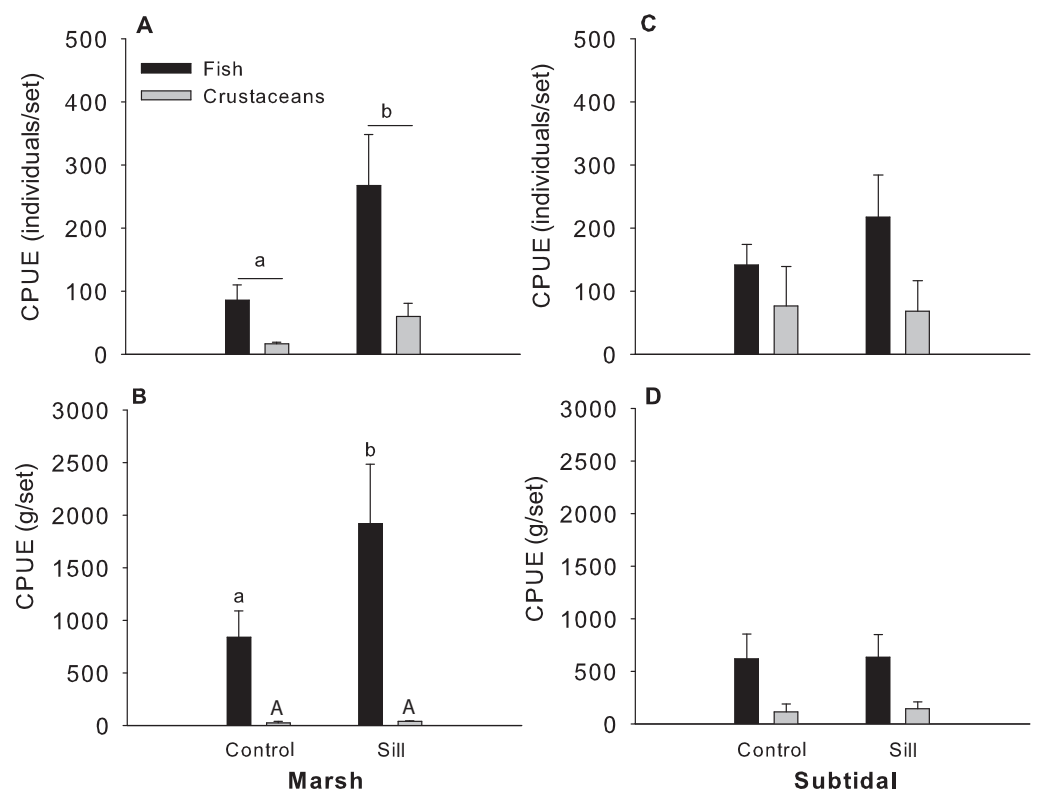

FIG. 2. Mean catch per unit effort (CPUE): (A) individuals per fyke net set in salt marsh; (B) biomass (g) per fyke net set in salt marsh; (C) individuals per seine net set in subtidal habitats; and (D) biomass (g) per seine net set in subtidal habitats. Error bars are standard error (SE). Black bars with different lowercase letters and gray bars with different uppercase letters are significantly different $(P<0.05)$. 
$\mathrm{df}=14, P>|t|=0.08)$. The species diversity $\left(H^{\prime}\right)$ of fishes within the marsh (two fyke net sets) at sill sites was greater than at control sites $(t$ ratio $=-3.83$, $\mathrm{df}=14, P>|t|=0.002$ ).

Transient fishes such as mullets (Mugil spp.), pinfish (Lagodon rhomboides), spot (Leiostomus xanthurus), mojarra (Eucinostomus spp.), flounders (Paralichthys spp.), speckled trout (Cynoscion nebulosus), pigfish (Orthopristis chrysoptera), and silver perch (Bairdiella chrysoura) dominated the fyke net catches within the marsh at both sill and control sites (making up 93\% of the individuals and $92 \%$ of the biomass and $97 \%$ of the individuals and $95 \%$ of the biomass, respectively), although total abundance and biomass of each species was greater within the marsh at sill sites than control sites (Table 1). Marsh resident species, such as mummichogs (Fundulus heteroclitus) and striped killifish (Fundulus majalis), were also more abundant within the marsh at sill sites than control sites (Table 1). Marsh residents made up 7\% of the individuals and $8 \%$ of the biomass caught within the marsh at sill sites and only $3 \%$ of the individuals

TABLE 1. Catch rates (individual [ind.] and biomass) and mean standard length (SL) of species caught in salt marsh habitat at CI sill and control marsh sites in North Carolina, USA.

\begin{tabular}{|c|c|c|c|c|c|c|}
\hline \multirow[b]{2}{*}{ Species } & \multicolumn{3}{|c|}{ Sill } & \multicolumn{3}{|c|}{ Control } \\
\hline & Ind./6 h & $\begin{array}{l}\text { Biomass } \\
(\mathrm{g} / 6 \mathrm{~h})\end{array}$ & $\mathrm{SL}(\mathrm{mm})$ & Ind./6 h & $\begin{array}{l}\text { Biomass } \\
(\mathrm{g} / 6 \mathrm{~h})\end{array}$ & $\mathrm{SL}(\mathrm{mm})$ \\
\hline \multicolumn{7}{|l|}{ Fishes } \\
\hline Mugil spp. (T, P) & $109.1(65.9)$ & $966.8(490.6)$ & $91.2(1.8)$ & $9.6(6.0)$ & $190.3(124.5)$ & $89.8(4.0)$ \\
\hline Lagodon rhomboides $(\mathrm{T}, \mathrm{P})$ & $104.5(7.9)$ & $543.0(134.9)$ & $54.1(0.8)$ & $63.8(16.5)$ & $457.9(134.9)$ & $58.4(1.0)$ \\
\hline Leiostomus xanthurus $(\mathrm{T}, \mathrm{P})$ & $18.4(5.5)$ & $72.1(9.8)$ & $56.4(1.1)$ & $5.7(2.5)$ & $19.9(9.9)$ & $51.5(1.1)$ \\
\hline Eucinostomus spp. (T, P) & $9.7(3.7)$ & $23.9(9.1)$ & $43.0(1.2)$ & $1.1(0.1)$ & $1.9(0.2)$ & $46.0(4.4)$ \\
\hline Fundulus heteroclitus (R) & $9.6(4.1)$ & $41.5(20.4)$ & $48.5(0.8)$ & $1.3(1.0)$ & $3.2(1.8)$ & $45.9(1.9)$ \\
\hline Fundulus majalis $(\mathrm{R})$ & $5.5(1.8)$ & $27.2(10.5)$ & $58.7(2.1)$ & $0.4(0.1)$ & $1.9(0.8)$ & $61.4(4.9)$ \\
\hline Menidia menidia $(\mathrm{R})$ & $2.0(2.0)$ & $2.0(1.5)$ & $45.5(2.8)$ & $0.1(0.1)$ & $0.1(0.0)$ & $41.0(0.0)$ \\
\hline Paralichthys spp. (T, P) & $1.9(0.7)$ & $87.6(8.7)$ & $141.7(17.3)$ & $0.5(0.2)$ & $58.7(36.2)$ & $223.6(50.0)$ \\
\hline Cynoscion nebulosus $(\mathrm{T}, \mathrm{P})$ & $1.4(0.5)$ & $10.9(2.8)$ & $63.7(7.6)$ & $0.4(0.1)$ & $19.4(10.0)$ & $117.6(27.9)$ \\
\hline Orthopristis chrysoptera $(\mathrm{T})$ & $1.4(0.5)$ & $21.2(6.9)$ & $80.7(3.8)$ & $0.7(0.3)$ & $14.7(6.1)$ & $89.5(6.1)$ \\
\hline Bairdiella chrysoura $(\mathrm{T})$ & $1.0(0.1)$ & $24.1(5.5)$ & $106.3(5.2)$ & $0.6(0.2)$ & $14.4(2.7)$ & $102.0(10.9)$ \\
\hline Menidia beryllina $(\mathrm{R}, \mathrm{P})$ & $0.5(0.3)$ & $1.0(0.7)$ & $55.9(3.5)$ & $0.0(0.0)$ & $0.0(0.0)$ & $0.0(0.0)$ \\
\hline Cyprinodon variegatus $(\mathrm{R})$ & $0.4(0.4)$ & $1.4(1.4)$ & $42.3(1.6)$ & $0.0(0.0)$ & $0.0(0.0)$ & $0.0(0.0)$ \\
\hline Symphurus plagiusa $(\mathrm{T}, \mathrm{P})$ & $0.4(0.1)$ & $1.3(0.6)$ & $59.5(7.4)$ & $0.1(0.1)$ & $0.1(0.1)$ & $41.3(4.3)$ \\
\hline Anchoa mitchilli $(\mathrm{T}, \mathrm{P})$ & $0.4(0.3)$ & $0.2(0.3)$ & $48.7(2.4)$ & $0.1(0.1)$ & $0.4(0.2)$ & $69.0(0.0)$ \\
\hline Lutjanus griseus $(\mathrm{T})$ & $0.4(0.2)$ & $0.5(0.3)$ & $33.8(5.0)$ & $0.1(0.1)$ & $0.1(0.1)$ & $36.0(1.0)$ \\
\hline Sciaenops ocellatus $(\mathrm{T}, \mathrm{P})$ & $0.2(0.1)$ & $20.6(10.5)$ & $181.7(17.0)$ & $0.1(0.1)$ & $15.8(15.8)$ & $245.5(94.5)$ \\
\hline Strongylura marina $(\mathrm{T})$ & $0.2(0.0)$ & $0.8(0.3)$ & $148.3(24.9)$ & $0.4(0.3)$ & $1.4(1.4)$ & $64.6(32.3)$ \\
\hline Anguilla rostrata $(\mathrm{T})$ & $0.1(0.1)$ & $11.8(7.8)$ & $413.0(107)$ & $0.1(0.1)$ & $20.7(20.7)$ & $468.5(46.5)$ \\
\hline Opsanus tau $(\mathrm{R}, \mathrm{P})$ & $0.1(0.1)$ & $48.6(48.6)$ & $207.0(37.0)$ & $0.1(0.1)$ & $16.2(16.2)$ & $204.0(0.0)$ \\
\hline $\begin{array}{l}\text { Archosargus probatocephalus } \\
\text { (T) }\end{array}$ & $0.1(0.0)$ & $25.0(0.0)$ & $0.0(0.0)$ & $0.0(0.0)$ & $0.0(0.0)$ & \\
\hline Chasmodes saburrae $(\mathrm{T})$ & $0.1(0.1)$ & $0.1(0.1)$ & $50.0(0.0)$ & $0.1(0.1)$ & $0.3(0.3)$ & $53.0(0.0)$ \\
\hline Hypsoblennius hentz (T) & $0.1(0.1)$ & $0.1(0.1)$ & $45.0(0.0)$ & $0.0(0.0)$ & $0.0(0.0)$ & $0.0(0.0)$ \\
\hline Sphyraena barracuda $(\mathrm{T})$ & $0.1(0.1)$ & $12.5(12.5)$ & $190.0(0.0)$ & $0.0(0.0)$ & $0.0(0.0)$ & $0.0(0.0)$ \\
\hline Sphyraena borealis $(\mathrm{T})$ & $0.1(0.1)$ & $1.0(1.0)$ & $127.0(0.0)$ & $0.0(0.0)$ & $0.0(0.0)$ & $0.0(0.0)$ \\
\hline Trachinotus falcatus $(\mathrm{T})$ & $0.1(0.1)$ & $0.1(0.1)$ & $35.0(0.0)$ & $0.1(0.1)$ & $0.0(0.0)$ & $0.0(0.0)$ \\
\hline Oligoplites saurus $(\mathrm{T})$ & $0.0(0.0)$ & $0.0(0.0)$ & $0.0(0.0)$ & $0.1(0.1)$ & $0.1(0.1)$ & $35.0(0.0)$ \\
\hline Synodus foetens $(\mathrm{T})$ & $0.0(0.0)$ & $0.0(0.0)$ & $0.0(0.0)$ & $0.1(0.1)$ & $0.3(0.3)$ & $83.0(0.0)$ \\
\hline \multicolumn{7}{|l|}{ Crustaceans } \\
\hline Palaemonetes spp. (R, P) & $31.9(15.0)$ & $7.1(3.4)$ & $22.0(0.3)$ & $2.3(1.7)$ & $0.4(0.3)$ & $21.6(0.5)$ \\
\hline Callinectes sapidus $(\mathrm{T}, \mathrm{P})$ & $18.0(5.6)$ & $728.6(70.1)$ & $74.3(1.9)$ & $12.0(2.1)$ & $554.9(120.6)$ & $74.6(2.3)$ \\
\hline Penaeus spp. $(\mathrm{T}, \mathrm{P})$ & $9.4(1.0)$ & $17.4(5.0)$ & $49.3(1.4)$ & $1.9(0.5)$ & $5.5(1.5)$ & $55.9(3.2)$ \\
\hline Menippe mercenaria $(\mathrm{T})$ & $0.1(0.1)$ & $14.3(14.3)$ & $196.0(0.0)$ & $0.1(0.1)$ & $17.1(17.1)$ & $79.0(0.0)$ \\
\hline
\end{tabular}

Notes: All values are shown with standard error (SE) in parentheses. Catch rates were determined by setting nets out during a night spring high tide and recovering gear during the subsequent low tide, $\sim 6 \mathrm{~h}$ later. Transient species are defined as fishes that spend only a portion of their life cycle in the estuary and are denoted with a T. Resident species spend their entire life cycle within the estuary and are denoted with an R, after Peterson and Turner (1994) and Hettler (1989). Species that were caught within the marsh at the before-after-control-impact Pine Knoll Shores (BACI PKS) sill site post-construction are denoted with a P. Standard length measurements were taken for fish and shrimp; SL values for crabs denote carapace length. 

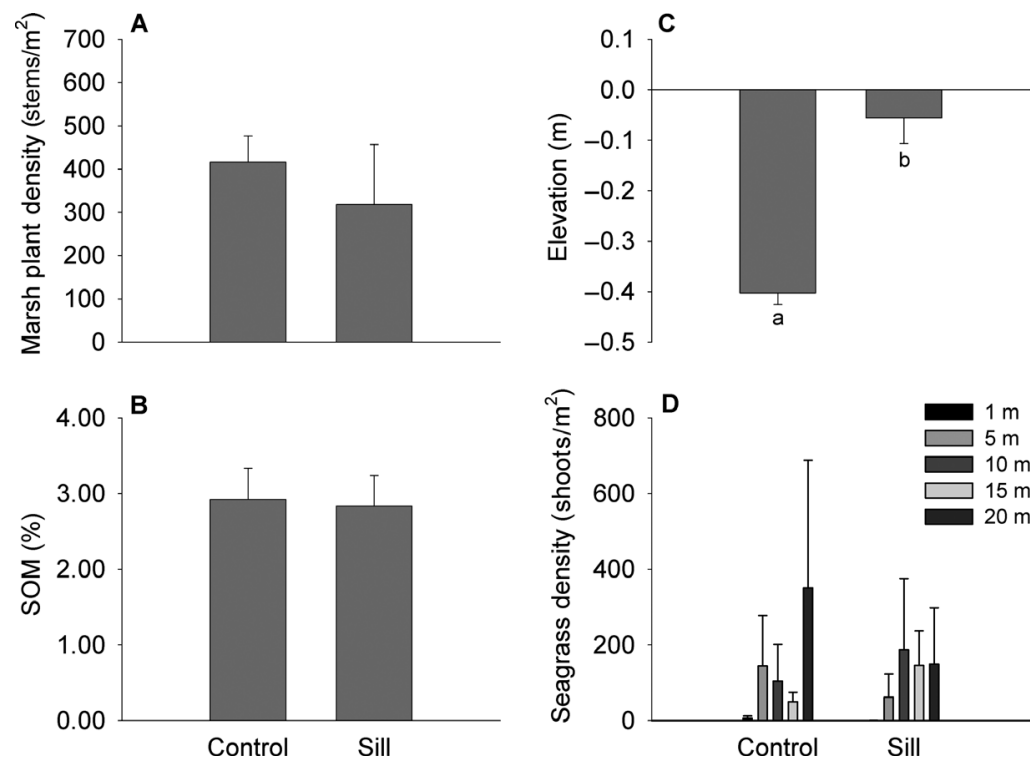

FIG. 3. Mean (A) total stem density across all species of marsh macrophytes; (B) sediment organic matter (SOM); (C) surface elevation (using North American vertical datum of 1988; NAVD88) of the mudflat within $1 \mathrm{~m}$ seaward of marsh edge; and (D) total seagrass shoot density across all species with increasing distance from the marsh edge $(1-20 \mathrm{~m})$ at $\mathrm{CI}$ control and sill sites. Error bars are SE. Bars with different lowercase letters are significantly different $(P<0.05)$.

and $5 \%$ of the biomass caught at control marsh sites. Crustacean catches within the marsh at both sill and control sites consisted of shrimp (Penaeid spp. and Palaemonetes spp.) and crabs (primarily blue crab, Callinectes sapidus), with catches of these species being greater within the marsh at sill sites than control sites (Table 1).

Catch rates and species diversity of nekton using seagrass patches or mudflat adjacent to sills or control sites were not significantly different based on seine net sampling (Fig. 2C,D, $P>0.1$; Appendix S2: Table S22). L. rhomboides dominated seine net catches at both sill and control sites, making up $77 \%$ and $82 \%$ of the individuals, respectively.

Mean total density of marsh macrophyte stems and mean SOM within the marsh did not differ between sill and control sites (Fig. 3A, B, $t$ ratio $=0.78, \mathrm{df}=$ 2, $P>|t|=0.51$ and $t$ ratio $=-0.92, \mathrm{df}=2, P>$ $|t|=0.46)$. Mean surface elevation of the unvegetated area between the sill and the landward marsh edge was greater than mean surface elevation within $1 \mathrm{~m}$ of marsh edge at control sites (Fig. 3C, $t$ ratio $=-6.16$, $\mathrm{df}=2, P>|t|=0.03$ ). Mean total density of seagrass shoots did not differ between sill and control marsh sites at any distance from the marsh edge (chi-squared $=0.25, \mathrm{df}=1, P>$ chi-squared $=0.62$, Fig. $3 \mathrm{D})$.

\section{BACI comparison}

There was no effect of sill construction on nekton catch rates within intertidal (fyke net) or subtidal habitats (seine net) less than $1 \mathrm{yr}$ post-construction at any of the sampled BACI sites (Fig. 4A-H, P > 0.1 , treatment by time interaction, Appendix S2: Table S3).

\section{CI and BACI sill comparison}

The mean difference in fyke net catch rates of fishes within salt marsh habitat between older CI PKS sill sites (3-8 yr post-construction) and paired control marsh sites was greater than the difference between fyke net catch rates at the BACI PKS sill site $(<1 \mathrm{yr}$ post-construction) and paired control marsh site (Fig. 5A, $t=14.4$, df $=2, P>|t|=$ $0.005)$. However, there was no analogous difference in crustacean fyke net catch rates $(t=2.7, \mathrm{df}=2$, $P>|t|=0.11)$. Only three of six resident species caught in fyke nets at the CI sill sites were caught at the BACI sill site (Table 1). Surface elevation (m) landward of the CI sills was greater than surface elevation landward of the BACI sill (Fig. $5 \mathrm{~B}, t=$ 5.52, df $=2, P>|t|=0.03)$. SOM (\%) landward of the CI sills was greater than SOM landward of the BACI sill (Fig. 5C, $t=4.92$, df $=2, P>|t|=$ $0.04)$. Total stem density of marsh macrophytes was greater at CI sills than at the BACI sill; however, this difference was not significant (Fig. 5D, $t=2.10$, df $=$ 2, $P>|t|=0.17)$.

\section{Comparison of sills, control marshes, and bulkheads}

Catch rates (individuals and biomass per trap set) of fishes were greater along the unvegetated edge of 

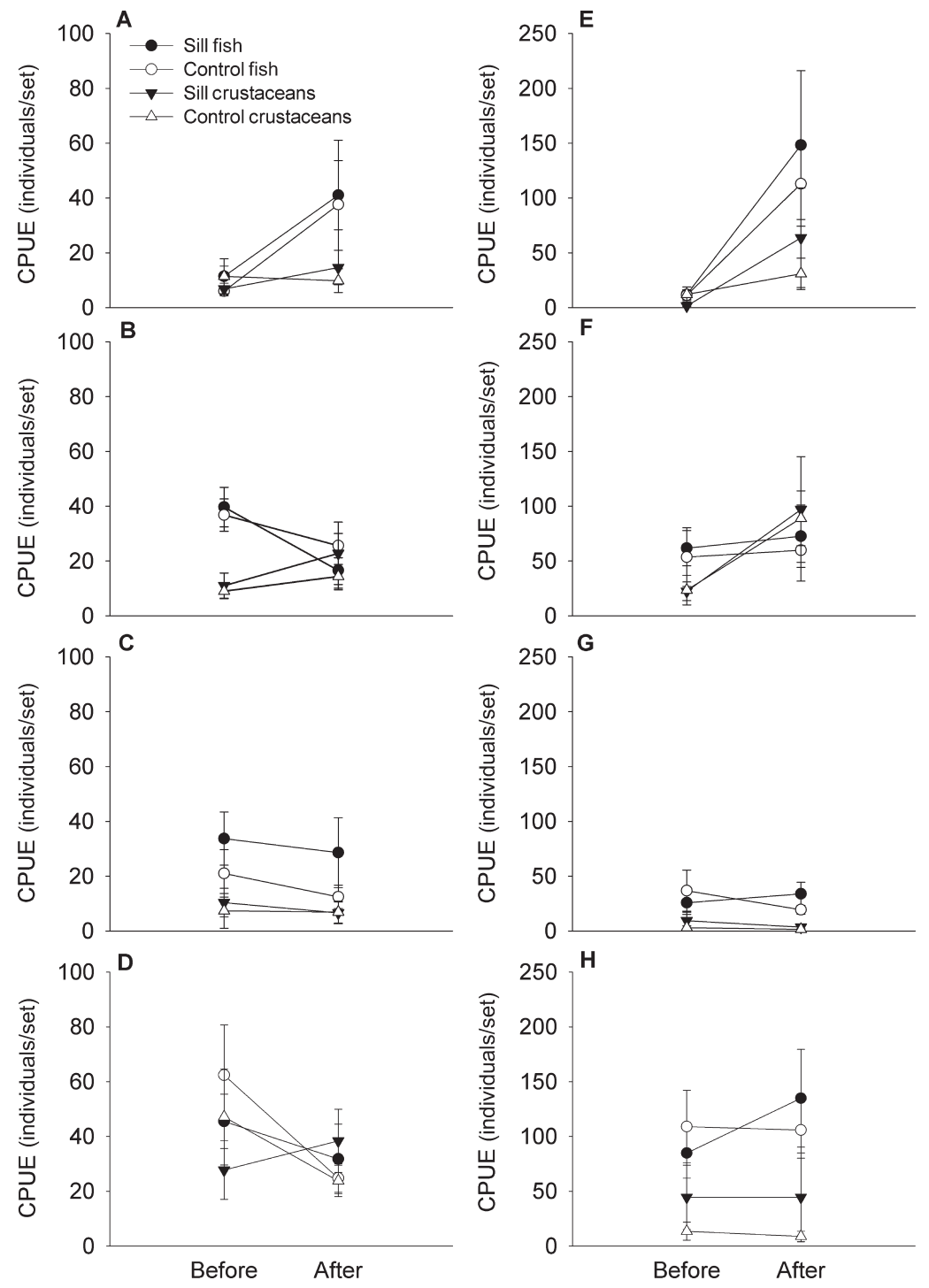

FIG. 4. Mean CPUE (individuals per set) before and after construction of the sill at Hatteras, Pine Knoll Shores, Jones Island, and Morris Landing in salt marsh (fyke net, A-D, respectively) and subtidal habitat (seine net, E-H, respectively). Error bars are SE.

sills than bulkheads (Fig. 6A, B, $P<0.05$, Tukey's post hoc tests; Appendix S2: Table S24), while control marsh catch rates were not different from catch rates at marsh sill or bulkheaded sites (Fig. 6A, B, $P>$ 0.05 , Tukey's post hoc tests). Trap catch rates of crustaceans were not different along the unvegetated edge between sill, control marsh, and bulkheaded sites (Fig. 6A, B, individuals per trap set, $F=1.14$, $\mathrm{df}=2, P=0.38$, and biomass per trap set, $F=$ 0.04 , $\mathrm{df}=2, P=0.95$ ). Resident marsh fishes made up $81 \%$ of the individuals and $76 \%$ of the biomass caught in traps at sill sites, while marsh residents made up only $11 \%$ of the individuals and $15 \%$ of the biomass caught at control marsh sites, and were completely absent from unvegetated bulkheaded sites
(Table 2). Epibiotic cover differed between sills, bulkheads, and along the edge of the control marshes (Fig. 6C; Appendix S2: Table S25). The pooled proportion of cover by filter-feeding bivalves (oysters and mytilid mussels) was greater on sills than on bulkheads or along control marsh edges $(P<0.05$, PERMANOVA pairwise tests). The proportion of cover by Semibalanus barnacles was greater on bulkheads than along control marsh edges $(P<0.05)$, but not different from sills $(P>0.05$, PERMANOVA pairwise tests). The pooled proportion of cover by other epibiota (tunicates, sponges, and bryozoans) was greater on bulkheads than along control marsh edges and sills $(P<0.05$, PERMANOVA pairwise tests). 

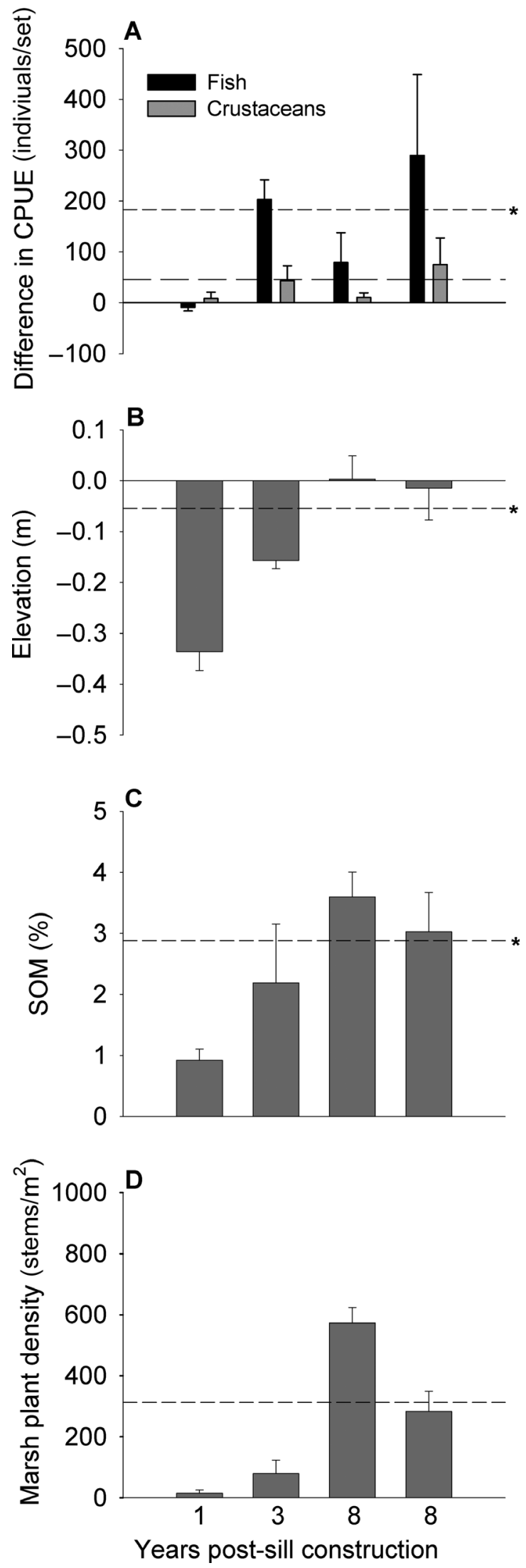

FIG. 5. (A) Change in fish CPUE (individuals per fyke net set) and crustacean CPUE between BACI $(<1$ yr post-construction) and $\mathrm{CI}$ ( $3 \mathrm{yr}$ [one site] and $8 \mathrm{yr}$ [two sites] post-construction) sill and control marsh sites in PKS. The short-dashed line represents the mean change in fish CPUE of the three CI sill sites and the long-dashed line represents the mean change in crustacean CPUE of the three CI sill sites. (B) Mean surface elevation (NAVD88) of the mudflat within $1 \mathrm{~m}$ landward of the sill; (C) mean SOM; and (D) mean density of marsh macrophytes at BACI and CI sill sites. The short-dashed line represents the mean surface elevation, SOM, or stem density of marsh macrophytes of the three CI sill sites. An asterisk indicates that this mean is significantly different from the mean of the BACI sill site one year after sill construction $(P<0.05)$. Error bars are SE.

\section{Discussion}

\section{Effects of sills on habitat use by fishes and crustaceans}

Marshes with sills support higher abundances and diversity of fishes and higher abundances of crustaceans than marshes without sills three or more years postconstruction (Figs. 2A, B and 6A, B), but this enhancement is not evident immediately after construction ( $\leq 1$ year; Fig. 4A-H and $5 \mathrm{~A}-\mathrm{D}$ ). A majority of the transient species that we caught were juveniles (Table 1), indicating that the fringing salt marshes at our sites probably serve as nursery habitat (Hettler 1989, Peterson and Turner 1994, Minello et al. 2003).

Marsh with sills may support higher abundances, biomass, and diversity of nekton via multiple mechanisms: (1) providing spatial refuges from predation for resident and juvenile fishes via increasing structural complexity of the habitat (Grabowski 2004); and (2) increasing food availability via the colonization and growth of epibiota on the sill itself and accumulation of organic material (Craft et al. 2003, Bulleri and Chapman 2010). Epibiota found on the sill (Fig. 6C), such as oysters (e.g., Crassostrea virginica), mytilid mussels, Semibalanus barnacles, and bryozoans (Bugula spp.) occur naturally on intertidal oyster reefs (Wells 1961, Fodrie et al. 2014) and may serve as food for many of the fish and crustaceans we caught, including L. rhomboides and C. sapidus (Peterson et al. 2003). We found no evidence that SOM was enhanced by the presence of a sill (Fig. 3B), rather SOM likely increased as a result of planting of marsh macrophytes landward of the sill. Therefore, the establishment of marsh seems necessary to provide SOM as trophic support for juvenile and resident nekton.

Differences in fish catch rates, particularly of marsh residents, between 1- and 3-year-old sills (Fig. 5A) may be a consequence of any of several physical and biological differences in <1-year-old BACI and $\geq 3$-year-old CI sill sites. A lower mean surface elevation directly landward of the sill $(-0.336 \mathrm{~m}$ NAVD88) at the PKS BACI sill site when compared to older PKS CI sill sites ( -0.166 to $0.003 \mathrm{~m}$ NAVD88) meant greater water depths at high tide (Fig. 5B). Deeper water facilitates more access of large predators to the 

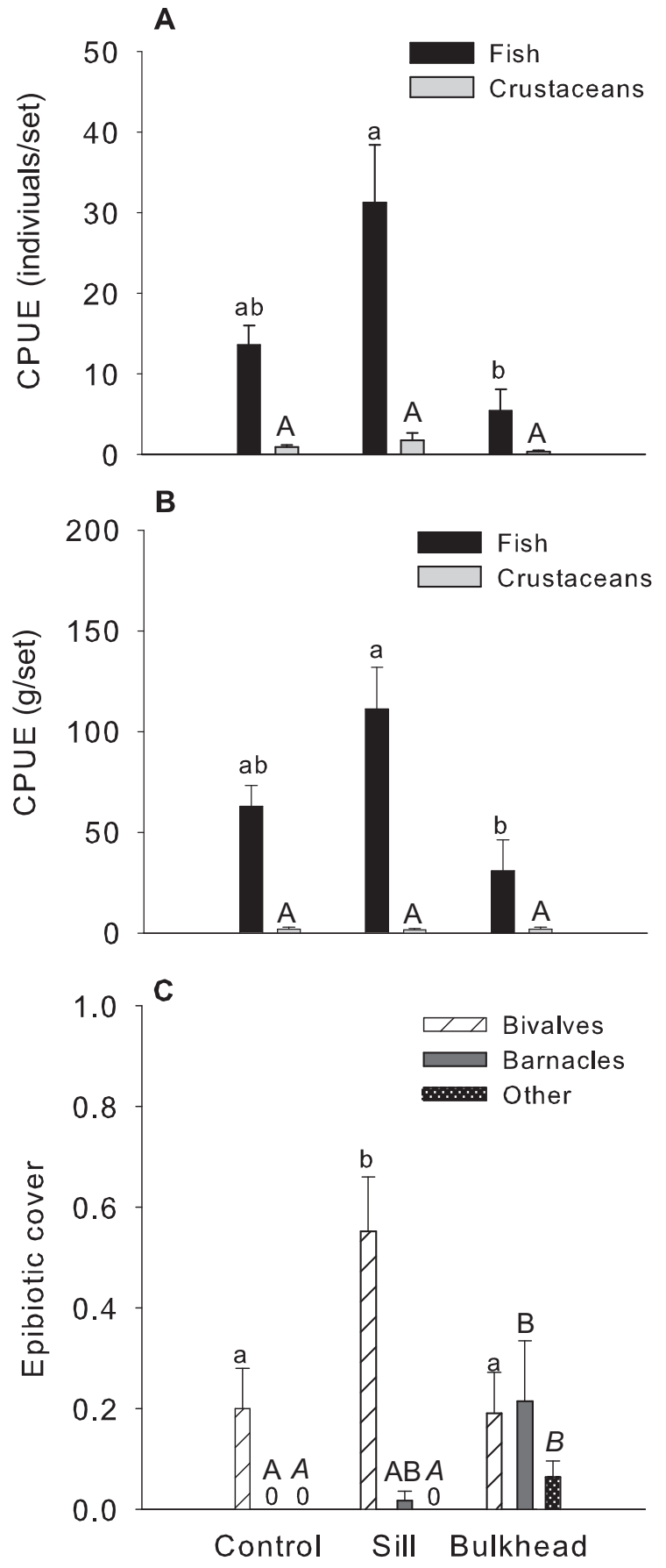

FIG. 6. Mean fish and crustacean CPUE: (A) individuals per trap set and (B) biomass ( $\mathrm{g}$ ) per trap set along the unvegetated edge of sills, control marshes, and bulkheads. (C) Proportion of coverage of bivalves (oysters and ribbed mussels), barnacles, and other epibiota (tunicates, bryozoans, and sponges) on stone sills, on the sand/mud substrate the edge of control marshes, and on bulkheads. Black bars or hatched bars with different lowercase letters, light gray bars or dark gray bars with different uppercase letters, and black dotted bars with different uppercase italic letters are significantly different $(P<$ 0.05). Error bars are SE. marsh and thus potentially reduces densities of small resident and juvenile fishes found along the marsh edge (via predation or behavioral avoidance by prey). Ruiz et al. (1993) found that densities and survivorship of juvenile fishes increased with decreasing depth and most predators of these species were found at a depth of $0.7 \mathrm{~m}$ or greater. This depth is approximately the equivalent mean depth during high tide at an elevation of $-0.2 \mathrm{~m}$ NAVD88 at our PKS study sites. Thus, the $<1$-year-old PKS BACI sill had greater access for predators than the $\geq 3$-year-old PKS CI sills. However, shallower depths along the marsh edge can also lead to reduced access for all nekton as the tide falls; therefore, this potential predation refuge may only be available at high tide. The PKS BACI sill site also had a lower SOM content than the older PKS CI sill sites (Fig. 5C), indicating that the PKS BACI sill provided less organic material and detritus for benthic-feeding species, such as Mugil spp. and Palaemonetes spp., to consume than the PKS CI sill sites. Fewer refuges from predation and lower food resource availability at the younger PKS BACI sill site as compared to the older PKS CI sill sites may have led to lower fish abundances. Finally, the PKS BACI sill site tended to have lower total stem densities of all marsh macrophytes, and therefore lower structural complexity, when compared to the PKS CI sill sites (Fig. 5D), although this difference was not statistically significant. Salt marsh macrophytes typically need multiple growing seasons to clonally expand and cover a site, and sediment surface elevation and SOM typically increase with salt marsh age, if sediment supply is adequate and subsidence is not occurring (Craft et al. 2002, 2003). We speculate that these results may indicate that the presence of a sill structure alone may not enhance fish use of intertidal habitat and that marsh macrophyte establishment (either through planting or natural recruitment) may be a critical aspect of enhanced of fish nursery habitat, although this hypothesis has yet to be tested.

We acknowledge that one of the shortcomings of control-impact designs is that observed differences between impact and control sites may be due to intrinsic differences in the sites, rather than differences caused by the "impact" of interest (Osenberg et al. 1994). However, as stated in Methods, we have made efforts to minimize site-specific differences that may affect nekton catch rates. There are also potential concerns (e.g., differences in sites) with CI (sill post-construction vs. control marsh) studies and with substituting space for time by comparing sill sites of varying ages to predict the trajectory of habitat development and nekton use of living shorelines. However, we used a combination of approaches (e.g., intensive sampling of nekton at multiple pairs of sill and control sites, measurements of multiple habitat characteristics) to evaluate the effects of living shorelines on nekton use. Despite these concerns, our results are consistent with the findings of other, 
complimentary studies (no enhancement of nekton 1 year post-construction of sills [Currin et al. 2007], enhancement of nekton 2-3 years post-construction of oyster reefs [Scyphers et al. 2011, La Peyre et al. 2014]).

In contrast to the observed enhancement of fish and crustacean abundances and fish diversity within the marsh at older sill sites (fyke net data), seine data suggest that the presence of a sill does not increase abundance or diversity of nekton within seaward seagrass or mudflat habitats, regardless of the age of the sill (Figs. 2C,D, $4 \mathrm{E}-\mathrm{H})$. Although not directly comparable due to different gear types being used for sampling, the nekton community occupying seagrass patches seaward of the sills was dominated by the same species that dominated the salt marsh catches (e.g., Mugil spp., L. rhomboides, L. xanthurus, Eucinostomus spp., and Paralichthys spp.), although L. rhomboides made up a larger percentage of the catches in seagrass. This result may be a consequence of high variability in seagrass shoot density and patchiness of seagrass cover at the marsh sill and control sites (Fig. 3D). Additionally, the unvegetated corridor between the sill or control marsh and the beginning of a seagrass patch was typically $5 \mathrm{~m}$ or greater in width, which could have precluded nekton from crossing readily to utilize both structured habitats (Micheli and Peterson 1999, Gilliam and Fraser 2001). Sandflat or mudflat corridors between structured habitats may have higher predation rates than vegetated habitats and may serve as a barrier between habitats for juvenile nekton (Irlandi and Crawford 1997, Micheli and Peterson 1999, Jelbart et al. 2006, Rozas et al. 2011).

\section{Comparison of sills to control marshes and bulkheads}

Higher abundances of fishes at sill sites relative to bulkhead sites indicated that the unvegetated habitat adjacent to sills was serving as a more suitable habitat for fishes than the unvegetated habitat adjacent to bulkheads (Fig. 6A,B). The difference in catch rates was driven primarily by the absence of resident fishes such as $F$. heteroclitus and $F$. majalis at bulkhead sites (Table 2). There was a trend of increasing catch rates (individuals per trap set) of crustaceans from bulkheads to control marshes to sills, although overall catches were low across all shoreline types and differences in catch rates were not statistically significant. Although catch rates of crustaceans were not significantly different between bulkheads and marsh sills, Palaemonetes spp., another marsh resident, was notably absent from the bulkheaded sites (Table 2). Both resident and juvenile transient species benefit from unvegetated edge adjacent to salt marsh (Lipcius et al. 2005); however, resident species also utilize the interior marsh during high tide (Peterson and Turner 1994). This dependency on the marsh interior may explain the absence of resident species at bulkheaded sites.

TABLE 2. Catch rates (individuals and biomass) and mean standard length (SL) of species caught in salt marsh edge habitat at sill, control marsh, and bulkhead sites.

\begin{tabular}{|c|c|c|c|c|c|c|c|c|c|}
\hline \multirow[b]{2}{*}{ Species } & \multicolumn{3}{|c|}{ Sill } & \multicolumn{3}{|c|}{ Control } & \multicolumn{3}{|c|}{ Bulkhead } \\
\hline & Ind./4 h & $\begin{array}{l}\text { Biomass } \\
(\mathrm{g} / 4 \mathrm{~h})\end{array}$ & $\mathrm{SL}(\mathrm{mm})$ & $\underset{\mathrm{h}}{\text { Ind./4 }}$ & $\begin{array}{l}\text { Biomass } \\
(\mathrm{g} / 4 \mathrm{~h})\end{array}$ & $\mathrm{SL}(\mathrm{mm})$ & $\begin{array}{l}\text { Ind./4 } \\
\mathrm{h}\end{array}$ & $\begin{array}{l}\text { Biomass } \\
(\mathrm{g} / 4 \mathrm{~h})\end{array}$ & $\begin{array}{c}\mathrm{SL} \\
(\mathrm{mm})\end{array}$ \\
\hline \multicolumn{10}{|l|}{ Fish } \\
\hline Fundulus heteroclitus (R) & $23.7(9.0)$ & $79.3(30.3)$ & $51.1(0.6)$ & $1.3(0.6)$ & $8.2(4.1)$ & $60.2(29.8)$ & $0.0(0.0)$ & $0.0(0.0)$ & $0.0(0.0)$ \\
\hline Lagodon rhomboides $(\mathrm{T})$ & $4.7(2.7)$ & $20.4(7.5)$ & $50.8(1.1)$ & $10.2(2.7)$ & $44.1(15.3)$ & $54.3(1.6)$ & $5.2(2.4)$ & $21.7(12.2)$ & $53.8(0.9)$ \\
\hline Fundulus majalis $(\mathrm{R})$ & $0.9(0.2)$ & $3.8(2.5)$ & $57.9(5.3)$ & $0.2(0.2)$ & $1.2(1.2)$ & $70.0(15.8)$ & $0.0(0.0)$ & $0.0(0.0)$ & $0.0(0.0)$ \\
\hline $\begin{array}{l}\text { Orthopristis } \\
\quad \text { chrysoptera }(\mathrm{T})\end{array}$ & $0.7(0.2)$ & $4.7(1.9)$ & $63.3(2.4)$ & $1.7(0.2)$ & $9.2(2.8)$ & $62.4(21.9)$ & $0.5(0.2)$ & $4.1(2.2)$ & $67.3(8.7)$ \\
\hline $\begin{array}{l}\text { Cyprinodon variegatus } \\
\text { (R) }\end{array}$ & $0.5(0.3)$ & $1.0(0.5)$ & $38.3(1.7)$ & $0.0(0.0)$ & $0.0(0.0)$ & $0.0(0.0)$ & $0.0(0.0)$ & $0.0(0.0)$ & $0.0(0.0)$ \\
\hline $\begin{array}{l}\text { Archosargus } \\
\quad \text { probatocephalus }(\mathrm{T})\end{array}$ & $0.3(0.3)$ & $0.8(0.8)$ & $40.8(1.5)$ & $0.0(0.0)$ & $0.0(0.0)$ & $0.0(0.0)$ & $0.0(0.0)$ & $0.0(0.0)$ & $0.0(0.0)$ \\
\hline Eucinostomus spp. (T) & $0.1(0.1)$ & $0.2(0.3)$ & $39.0(0.0)$ & $0.0(0.0)$ & $0.0(0.0)$ & $0.0(0.0)$ & $0.0(0.0)$ & $0.0(0.0)$ & $0.0(0.0)$ \\
\hline Cynoscion nebulosus $(\mathrm{T})$ & $0.1(0.1)$ & $0.8(0.8)$ & $95.0(0.0)$ & $0.0(0.0)$ & $0.0(0.0)$ & $0.0(0.0)$ & $0.0(0.0)$ & $0.0(0.0)$ & $0.0(0.0)$ \\
\hline Lutjanus griseus $(\mathrm{T})$ & $0.1(0.1)$ & $0.2(0.2)$ & $51.0(0.0)$ & $0.1(0.1)$ & $1.0(1.0)$ & $80.0(0.0)$ & $0.1(0.1)$ & $0.7(0.6)$ & $71.0(0.0)$ \\
\hline Symphurus plagiusa $(\mathrm{T})$ & $0.0(0.0)$ & $0.0(0.0)$ & $0.0(0.0)$ & $0.1(0.1)$ & $0.1(0.1)$ & $151.0(0.0)$ & $0.0(0.0)$ & $0.0(0.0)$ & $0.0(0.0)$ \\
\hline Anguilla rostrata $(\mathrm{T})$ & $0.0(0.0)$ & $0.0(0.0)$ & $0.0(0.0)$ & $0.0(0.0)$ & $0.0(0.0)$ & $0.0(0.0)$ & $0.1(0.1)$ & $3.0(3.1)$ & $310.0(0.0)$ \\
\hline Hypsoblennius hentz $(\mathrm{T})$ & $0.0(0.0)$ & $0.0(0.0)$ & $0.0(0.0)$ & $0.1(0.1)$ & $0.2(0.1)$ & $44.5(0.0)$ & $0.0(0.0)$ & $0.0(0.0)$ & $0.0(0.0)$ \\
\hline \multicolumn{10}{|l|}{ Crustaceans } \\
\hline Palaemonetes spp. (R) & $1.5(0.7)$ & $0.3(0.2)$ & $23.4(0.7)$ & $0.3(0.07)$ & $0.1(0.0)$ & $23.5(0.0)$ & $0.0(0.0)$ & $0.0(0.0)$ & $0.0(0.0)$ \\
\hline Penaeus spp. (T) & $0.1(0.1)$ & $0.5(0.3)$ & $67.0(4.0)$ & $0.5(0.1)$ & $0.8(0.7)$ & $52.8(3.1)$ & $0.2(0.2)$ & $1.0(1.1)$ & $69.7(5.7)$ \\
\hline Panopeus herbstii (R) & $0.1(0.1)$ & $0.5(0.5)$ & $29.0(0.0)$ & $0.0(0.0)$ & $0.0(0.0)$ & $0.0(0.0)$ & $0.0(0.0)$ & $0.0(0.0)$ & $0.0(0.0)$ \\
\hline
\end{tabular}

Notes: All values are shown with SE in parentheses. Catch rates were determined by setting traps $2 \mathrm{~h}$ before high tide and collecting $2 \mathrm{~h}$ after high tide ( $\sim 4-\mathrm{h}$ increment). Transient and resident species are as in Table 1. 
Bivalves, such as $C$. virginica and mytilid mussels, were the dominant epibiota on sills, while barnacles formed a larger proportion of the cover on bulkheads (Fig. 6C). Thus, the epibiotic community on sills resembles that of an intertidal oyster reef more so than that on bulkheads (Wells 1961, Fodrie et al. 2014). Nekton that use intertidal oyster reefs for refuge and food resources, such as oyster toadfish (Opsanus tau) and A. probatocephalus (Peterson et al. 2003), would likely receive similar benefits from stone sills once the epibiotic community has become established. Additionally, the relief and geometry of a sill is closer to that of an oyster reef than is a vertical bulkhead's geometry. Therefore, a sill is likely to provide refuge and resources more similar to those provided by oyster reefs (Chapman and Blockley 2009, Scyphers et al. 2011). Grabowski et al. (2005) and Geraldi et al. (2009) found that restored oyster reefs adjacent to salt marshes did not enhance abundances and were functionally redundant as fish habitat. However, the reefs constructed in both of those studies were lower in vertical relief and overall footprint than the sills sampled in our study. The marsh vegetation in the Grabowski et al. (2005) and Geraldi et al. (2009) studies may have also been older and better established than the young, recently planted marshes in our study. Therefore, increases in habitat structural complexity in the previously studied restored oyster reefs may have been less than increases associated with stone sills in our study.

\section{Design, site suitability, monitoring, and adaptive management of living shorelines}

To ensure that our results guide improved coastal defense strategies, we identify several aspects of living shorelines that warrant further research. If one major goal of a living shoreline is to sustain or enhance multiple ecosystem services, then additional studies targeting the delivery of all those services are needed. A better understanding of the relationship between sill placement relative to marsh plantings and/or design (e.g., size, distance from shore, number of drop-downs or gaps, orientation relative to shore) and accessibility of intertidal habitat to nekton is needed. Factors such as tidal regime, shoreline geomorphology, local sediment supply, fetch, and storm frequency will influence the trajectory of ecosystem development of a living shoreline and should be considered further (Ruggiero and McDougal 2001, Cahoon 2006, Ranasinghe and Turner 2006). Finally, the type of shallow subtidal habitats (e.g., seagrass or mudflat) that would be replaced by a structure should also be identified and the costs and benefits of habitat trade-offs should be assessed (vis-à-vis ecosystem services; Peterson and Lipcius 2003).

Despite the need for additional research on living shorelines, our results allow us to make some specific recommendations for implementing ecologically sustainable coastal defense strategies. First, we suggest wherever feasible, living shorelines (i.e., vegetation alone or, if necessary due to higher rates of erosion, vegetation with a sill) be used to stabilize a shoreline in lieu of bulkheads to provide better habitat for nekton. Also, sites should be monitored for a minimum of three years after construction and periodically thereafter to ensure that vegetation has become established, epibiota have colonized structures, and nektonic organisms are able to access the marsh, using the methodology presented in this study. If vegetation has not become established after three years, additional planting may be required. If nekton access is compromised, additional openings or a reduction in the height of the structure may be necessary to increase water flow or decrease sedimentation. Careful design and management of living shorelines may sustain ecosystem services, such as habitat provision and erosion protection, even as sea levels rise (Rodriguez et al. 2014) and storm intensity or frequency increases (Arkema et al. 2013). Therefore, living shorelines should be considered further as a preferred option for shoreline erosion protection that simultaneously enhances the ecosystem service of habitat enhancement for fish and mobile crustaceans.

\section{ACKNOWLEDGments}

We thank D. Acree, J. Shallcross, S. Bailey, J. Best, L. Lindgren, M. Hare, the Pine Knoll Shores Aquarium, and the North Carolina Coastal Federation for allowing us to survey their coastal properties. We also thank: J. Fear, S. Fegley, T. Rodriguez, S. Faulkner, and four anonymous reviewers for their guidance and reviews; and M. Brodeur, C. Coughlin, E. Davis, D. Keller, J. Lee, J. Morton, A. Popowich, M. Prafka, D. Roycroft, R. Sicheneder, P. Shrestha, and S. Zhang for assistance with field surveys. This research was funded by a NC Coastal Recreational Fishing License Grant to J. Bruno, C. Peterson, and R. Gittman, a NOAA NERRS graduate fellowship to R. Gittman, a grant to J. Fodrie from the National Science Foundation, NSF OCE1155628, and the University of North Carolina at Chapel Hill. The scientific results and conclusions, as well as any views or opinions expressed herein, are those of the author(s) and do not necessarily reflect the views of NOAA or the Department of Commerce.

\section{Literature Cited}

Anderson, M. 2005. Permutational multivariate analysis of variance: a computer program. Department of Statistics, University of Auckland, Auckland, New Zealand.

Arkema, K. K., G. Guannel, G. Verutes, S. A. Wood, A. Guerry, M. Ruckelshaus, P. Kareiva, M. Lacayo, and J. M. Silver. 2013. Coastal habitats shield people and property from sea-level rise and storms. Nature Climate Change 3:1-6.

Bell, J. D., and M. Westoby. 1986. Abundance of macrofauna in dense seagrass is due to habitat preference, not predation. Oecologia 68:205-209.

Bilkovic, D., and M. Roggero. 2008. Effects of coastal development on nearshore estuarine nekton communities. Marine Ecology Progress Series 358:27-39.

Bozek, C. M., and D. M. Burdick. 2005. Impacts of seawalls on saltmarsh plant communities in the Great Bay Estuary, 
New Hampshire USA. Wetlands Ecology Management 13:553-568.

Bulleri, F., and M. G. Chapman. 2010. The introduction of coastal infrastructure as a driver of change in marine environments. Journal of Applied Ecology 47:26-35.

Cahoon, D. R. 2006. A review of major storm impacts on coastal wetland elevations. Estuaries and Coasts 29:889-898.

Carpenter, S. R., et al. 2009. Science for managing ecosystem services: beyond the Millennium Ecosystem Assessment. Proceedings of the National Academy of Sciences USA 106:1305-1312.

Chapman, M. G., and D. J. Blockley. 2009. Engineering novel habitats on urban infrastructure to increase intertidal biodiversity. Oecologia 161:625-635.

Cheong, S. M., B. Silliman, P. P. Wong, B. van Wesenbeeck, C. K. Kim, and G. Guannel. 2013. Coastal adaptation with ecological engineering. Nature Climate Change 3:787-791.

Chesapeake Bay Trust. 2014. Living shorelines. Chesapeake Bay Trust, Annapolis, Maryland, USA. http://www.cbf.org/ Document. Doc? $\mathrm{id}=60$

Clarke, K. R., and R. N. Gorley. 2001. PRIMER 6.1.1 with PERMANOVA+ 1.0.1. Primer-E, Plymouth, UK.

Coasts, Oceans, Ports, and Rivers Institute (COPRI). 2014. Living shorelines database. http://mycopri.org/node/1467

Craft, C., S. Broome, and C. Campbell. 2002. Fifteen years of vegetation and soil development after brackish-water marsh creation. Restoration Ecology 10:248-258.

Craft, C., P. Megonigal, S. Broome, J. Stevenson, R. Freese, J. Cornell, L. Zheng, and J. Sacco. 2003. The pace of ecosystem development of constructed Spartina alterniflora marshes. Ecological Applications 13:1417-1432.

Crooks, S., and R. K. Turner. 1999. Integrated coastal management: sustaining estuarine natural resources. Pages 241-289 in D. B. Nedwell, and D. G. Raffaelli. Advances in ecological research, vol. 29. Academic Press, San Diego, California, USA.

Currin, C. A., W. S. Chappell, and A. Deaton. 2009. Developing alternative shoreline armoring strategies: the living shoreline approach in North Carolina. Pages 91-102 in H. Shipman, M. N Dethier, G. Gelfenbaum, K. L. Fresh, and R. S. Dinicola. Puget Sound shorelines and the impacts of armoring-Proceedings of the State of the Science Workshop. U.S. Geological Survey Scientific Investigations Report 2010-5254. USGS, Seattle, Washington, USA.

Currin, C. A., P. C. Delano, and L. M. Valdes-Weaver. 2007. Utilization of a citizen monitoring protocol to assess the structure and function of natural and stabilized fringing salt marshes in North Carolina. Wetlands Ecology Management 16:97-118.

Dahl, T. E., and S. M. Stedman. 2013. Status and trends of wetlands in the coastal watersheds of the coterminous United States 2004 to 2009. U.S. Department of the Interior, Fish and Wildlife Service and National Oceanic and Atmospheric Administration, National Marine Fisheries Service, Washington, D.C., USA.

Daoust, R. J., and D. L. Childers. 1998. Quantifying aboveground biomass and estimating net aboveground primary production for wetland macrophytes using a non-destructive phenometric technique. Aquatic Botany 62:115-133.

Doody, J. P. 2004. Coastal squeeze-an historical perspective. Journal of Coastal Conservation 10:129-138.

Drummond, S. P., and S. D. Connell. 2005. Quantifying percentage cover of subtidal organisms on rocky coasts: a comparison of the costs and benefits of standard methods. Marine and Freshwater Research 56:865-876.
Dugan, J. E., D. M. Hubbard, I. F. Rodil, D. L. Revell, and S. Schroeter. 2008. Ecological effects of coastal armoring on sandy beaches. Marine Ecology 29:160-170.

Fear, J., and B. Bendell. 2011. N.C. Division of Coastal Management assessment of 27 marsh sills in North Carolina: final report. N.C. Division of Coastal Management Assessment, Morehead City, North Carolina, USA.

Fodrie, F. J., et al. 2014. Classic paradigms in a novel environment: trajectory of restored intertidal oyster reefs governed by principals learned from rocky shores and saltmarsh wetlands. Journal of Applied Ecology 51(5):1314-1325.

Geraldi, N., S. Powers, K. Heck, and J. Cebrian. 2009. Can habitat restoration be redundant? Response of mobile fishes and crustaceans to oyster reef restoration in marsh tidal creeks. Marine Ecology Progress Series 389:171-180.

Gilliam, J. F., and D. F. Fraser. 2001. Movement in corridors: enhancement by predation threat, disturbance, and habitat structure. Ecology 82:258-273.

Gittman, R. K., F. J. Fodrie, A. M. Popowich, D. A. Keller, J. F. Bruno, C. A. Currin, C. H. Peterson, and M. F. Piehler. 2015. Engineering away our natural defenses: an analysis of shoreline hardening in the US. Frontiers in Ecology and the Environment 13:301-307.

Gittman, R. K., A. M. Popowich, J. F. Bruno, and C. H. Peterson. 2014. Marshes with and without sills protect estuarine shorelines from erosion better than bulkheads during a Category 1 hurricane. Ocean and Coastal Management 102:94-102.

Grabowski, J. 2004. Habitat complexity disrupts predator-prey interactions but not the trophic cascade on oyster reefs. Ecology 85:995-1004.

Grabowski, J. H., A. R. Hughes, and D. L. Kimbro. 2008. Habitat complexity influences cascading effects of multiple predators. Ecology 89:3413-3422.

Grabowski, J. H., A. R. Hughes, D. L. Kimbro, and M. A. Dolan. 2005. How habitat setting influences restored oyster reef communities. Ecology 86:1926-1935.

Grabowski, J. H., and C. H. Peterson. 2007. Restoring oyster reefs to recover ecosystem services. Pages 281-298 in K. Cuddington, W. G. Wilson, and A. Hastings, editors. Ecosystem engineers plants to protists. Academic Press, Burlington, Massachusetts, USA.

Hall, M., and O. Pilkey. 1991. Effects of hard stabilization on dry beach width for New Jersey. Journal of Coastal Research 7:771-785.

Hauxwell, J., J. Cebrian, C. Furlong, and I. Valiela. 2001. Macroalgal canopies contribute to eelgrass (Zostera marina) decline in temperate estuarine ecosystems. Ecology 82:1007-1022.

Hettler, W., Jr. 1989. Nekton use of regularly-flooded saltmarsh cordgrass habitat in North Carolina, USA. Marine Ecology Progress Series 56:111-118.

Hoegh-Guldberg, O., and J. F. Bruno. 2010. The impact of climate change on the world's marine ecosystems. Science 328:1523-1528.

Holm, S. 1979. A simple sequentially rejective multiple test procedure. Scandinavian Journal of Statistics 6:65-70.

Irlandi, E. A., and M. K. Crawford. 1997. Habitat linkages: the effect of intertidal saltmarshes and adjacent subtidal habitats on abundance, movement, and growth of an estuarine fish. Oecologia 110:222-230.

Jelbart, J. E., P. M. Ross, and R. M. Connolly. 2006. Fish assemblages in seagrass beds are influenced by the proximity of mangrove forests. Marine Biology 150:993-1002.

La Peyre, M. K., A. T. Humphries, S. M. Casas, and J. F. La Peyre. 2014. Temporal variation in development of 
ecosystem services from oyster reef restoration. Ecological Engineering 63:34 44.

Lipcius, R. N., R. D. Seitz, M. S. Seebo, and D. ColónCarrión. 2005. Density, abundance and survival of the blue crab in seagrass and unstructured salt marsh nurseries of Chesapeake Bay. Journal of Experimental Marine Biology and Ecology 319:69-80.

Lucrezi, S., T. A. Schlacher, and W. Robinson. 2010. Can storms and shore armouring exert additive effects on sandy-beach habitats and biota? Marine and Freshwater Research 61:951.

Micheli, F., and C. H. Peterson. 1999. Estuarine vegetated habitats as corridors for predator movements. Conservation Biology 13:869-881.

Millennium Ecosystem Assessment (MEA). 2005. Ecosystems and human well-being: wetlands and water-synthesis. World Resources Institute, Washington, D.C., USA.

Minello, T. J., K. W. Able, M. P. Weinstein, and C. Hays. 2003. Salt marshes as nurseries for nekton: testing hypotheses on density, growth and survival through meta-analysis. Marine Ecology Progress Series 246:39-59.

National Research Council (NRC) Committee on Mitigating Shore Erosion along Sheltered Coasts. 2007. Mitigating Shore Erosion along Sheltered Coasts. National Academies Press, Washington, D.C, USA.

Neckles, H. A., M. Dionne, D. M. Burdick, C. T. Roman, R. Buchsbaum, and E. Hutchins. 2002. A monitoring protocol to assess tidal restoration of salt marshes on local and regional scales. Restoration Ecology 10:556-563.

Orth, R. J., K. L. Heck, and J. van Montfrans. 1984. Faunal communities in seagrass beds: a review of the influence of plant structure and prey characteristics on predator-prey relationships. Estuaries 7:339.

Osenberg, C. W., R. J. Schmitt, S. J. Holbrook, K. E. AbuSaba, and A. R. Flegal. 1994. Detection of environmental impacts: natural variability, effect size, and power analysis. Ecological Applications 4:16-30.

Peterson, C., J. Grabowski, and S. Powers. 2003. Estimated enhancement of fish production resulting from restoring oyster reef habitat: quantitative valuation. Marine Ecology Progress Series 264:249-264.

Peterson, C. H., and R. N. Lipcius. 2003. Conceptual progress towards predicting quantitative ecosystem benefits of ecological restorations. Marine Ecology Progress Series 264:297-307.

Peterson, G., and R. Turner. 1994. The value of salt marsh edge vs interior as a habitat for fish and decapod crustaceans in a Louisiana tidal marsh. Estuaries and Coasts 17:235-262.

Piazza, B. P., P. D. Banks, and M. K. La Peyre. 2005. The potential for created oyster shell reefs as a sustainable shoreline protection strategy in Louisiana. Restoration Ecology 13:499-506.

Pontee, N. 2013. Defining coastal squeeze: a discussion. Ocean and Coastal Management 84:204-207.
Ranasinghe, R., and I. L. Turner. 2006. Shoreline response to submerged structures: a review. Coastal Engineering 53:65-79.

Rodriguez, A. B., et al. 2014. Oyster reefs can outpace sea level rise. Nature Climate Change 4(6):493-497.

Rozas, L. P., and T. J. Minello. 1997. Estimating densities of small fishes and decapod crustaceans in shallow estuarine habitats: a review of sampling design with focus on gear selection. Estuaries 20:199-213.

Rozas, L. P., T. J. Minello, and D. D. Dantin. 2011. Use of shallow lagoon habitats by nekton of the northeastern Gulf of Mexico. Estuaries and Coasts 35:572-586.

Ruggiero, P., and W. G. McDougal. 2001. An analytic model for the prediction of wave setup, longshore currents and sediment transport on beaches with seawalls. Coastal Engineering 43:161-182.

Ruiz, G. M., A. H. Hines, and M. H. Posey. 1993. Shallow water as a refuge habitat for fish and crustaceans in nonvegetated estuaries: an example from Chesapeake Bay. Marine Ecology Progress Series 99:1-16.

SAS Institute Inc. 2012. JMP ${ }^{\circledR}$ Version 10.0. Cary, NC USA. Scyphers, S. B., S. P. Powers, K. L. Heck, Jr, and D. Byron. 2011. Oyster reefs as natural breakwaters mitigate shoreline loss and facilitate fisheries. PLoS ONE 6:1-12.

Seitz, R., R. Lipcius, N. Olmstead, M. Seebo, and D. Lambert. 2006. Influence of shallow-water habitats and shoreline development on abundance, biomass, and diversity of benthic prey and predators in Chesapeake Bay. Marine Ecology Progress Series 326:11-27.

Stunz, G., T. Minello, and L. Rozas. 2010. Relative value of oyster reef as habitat for estuarine nekton in Galveston Bay, Texas. Marine Ecology Progress Series 406:147-159.

Temmerman, S., P. Meire, T. J. Bouma, P. M. J. Herman, T. Ysebaert, and H. J. De Vriend. 2013. Ecosystem-based coastal defense in the face of global change. Nature 504:79-83.

Teo, S., and K. W. Able. 2003. Habitat use and movement of the mummichog (Fundulus heteroclitus) in a restored salt marsh. Estuaries 26:720-730.

Thieler, E. R., and R. S. Young. 1991. Quantitative evaluation of coastal geomorphological changes in South Carolina after Hurricane Hugo. Journal of Coastal Research SI $8: 187-200$.

Titus, J. 1998. Rising seas, coastal erosion, and the takings clause: how to save wetlands and beaches without hurting property owners. Maryland Law Review 57:1279-1318.

Törnqvist, T. E., and D. J. Meffert. 2008. Sustaining coastal urban ecosystems. Nature Geoscience 1:805-807.

Vitousek, P. M. 1997. Human domination of Earth's ecosystems. Science 277:494-499.

Wells, H. W. 1961. The fauna of oyster beds, with special reference to the salinity factor. Ecological Monographs $31: 239-266$.

\section{SUPPORTING INFORMATION}

Additional supporting information may be found in the online version of this article at http://onlinelibrary.wiley.com/ doi/10.1890/14-0716.1/suppinfo 